\title{
A Systematic Review of the Debate and the Researchers of Disruptive Innovation
}

\author{
Carlos Tadao Kawamoto ${ }^{1^{*}}$ and Renata Giovinazzo Spers ${ }^{1}$
}

\begin{abstract}
Despite the popularity of the term "disruptive innovation", its applications have taken on different meanings. Clayton Christensen is a prominent author in the field but his approach has not been applied in a consistent manner. To elucidate the use of the term in business studies, this paper employs a bibliometric approach to provide a descriptive analysis of researchers and their relevant works in the network formed by the related literature, in addition to distinguishing and grouping associated authors. The results suggest a dissimilarity of objectives between two subgroups using the term "disruptive innovation", and the discussion about Clayton Christensen's specific meaning of the term seems to make sense to only one of them.
\end{abstract}

Keywords: disruptive innovation; disruptive technology; innovation; disruption

Submitted: August $31^{\text {st }}, 2018$ / Approved: December $6^{\text {th }}, 2018$

\section{Introduction}

The terms "disruptive innovation" and "disruptive technology" have gained prominence in recent years, with academic interest evidenced by special editions of reputed journals dedicated to the theme of disruption, such as the Journal of Management Studies, Journal of Product Innovation Management, IEEE Transactions on Engineering Management and Technological Forecasting and Social Change, as well as by the terms' inclusion in management and innovation textbooks (e.g., Garud, Kumaraswamy \& Langlois, 2003; Besanko, Dranove, \& Shanley, 2004; Trott, 2008; and Hill, Jones, \& Schilling, 2015). The terms are usually associated with Clayton Christensen, whose academic papers obtained high citation grades and whose books achieved great commercial success. In 2011, The Economist magazine included Christensen's 1997 book, The Innovator's Dilemma, among the six classics in management literature of the past fifty years.

Despite Christensen's accomplishments, the concept of disruptive innovation generated well-known controversies in the field of management studies (Hopp, Antons, Kaminski, \& Salge, 2018a). An innovation that causes disruption in a market is not necessarily a disruptive innovation as Christensen defines it (Schimidt \& Druehl, 2008). If, on the one hand, media success or sales figures do not necessarily represent the truth about the development of Christensen's work, then some criticisms seem extreme, in terms of both the theoretical quality of his work and the originality of his contribution. The debate over the validity of Christensen's approach has been intense over the past decade, with exalted condemnations or nonconsensual modifications of the theory by some authors (e.g., Markides, 2006; Daneels, 2004; Markides, 2013; and King \& Baatartogtokh, 2015). Above all, the discussions manifest the existence of a dispute in this field of knowledge.

An important and possibly related fact about some of the criticisms is that, even with the frequent use of the term, the theory's concepts are not always applied in a consistent manner. It is not unusual for the expression "disruptive innovation" to be employed with a radical meaning that is distant from what was intended by Christensen. According to the Organization for Economic Cooperation and Development (OECD), for example, disruptive innovation "has a significant impact on a market and on the economic activity of firms in that market. This concept focuses on the impact of the innovations, as opposed to their novelty" (OECD, 2005, p.58). Famous examples such as Uber, which has already caused significant changes in the taxi industries of several cities around the world and is frequently referred to as a disruptive innovation, does not fit into the concept proposed by the theory's authors (Christensen, Raynor, \& McDonald, 2015). In another example of imprecise use, Souza and Takahashi (2012) disregarded the possibility of new market disruption when they stated that "the evolutionary trajectory of the performance of a disruptive innovation makes it eventually competitive in the main market (otherwise it is not a disruptive innovation)" (our translation, parentheses in the original, p.123). The authors reduce the predictive qualities of the approach when they suggest that the theory can only be explained ex post facto.

Semantic confusion is undesirable in scientific postulates. The conflict over the use of "disruptive innovation" in academic evaluations can reduce the relevant by-products from research and, consequently, the contributions to managers and their organizations. Hence, efforts to reduce asymmetries in terminological understanding are welcome. In English, where the word "disruption" already belongs to the language, the confusion between Christensen's sense and its popular meaning is apparent and raises heated discussions among some authors. In other languages that do not embrace the word "disruption" as a native term, such as Spanish or Portuguese, the confusion should be less frequent but still manifests itself and, therefore, the correct meaning must be clarified in specialized publications.

Attempts have been made to use bibliometric techniques to better comprehend the development of the field. From what is known, bibliometric analysis was applied with a focus on disruptive innovations in Pilkington (2009); Cândido (2011); Schiavi and Behr (2017);

(1) Economics, Business and Accounting School, University of São Paulo, São Paulo, SP, Brazil.

*Corresponding author: carlos.kawamoto@usp.br 
Li, Porter, and Suominen (2017) and Hopp, Antons, Kaminski, and Salge (2018b). Pilkington (2009) evaluated three hypotheses related to the impact of Christensen, and showed the authors' stable citations growth over time, eventually expanding to other areas of research beyond the strategy and management of organizations. Cândido (2011) assessed the evolution of the number of papers that contained the term "disruptive innovation" as a keyword, in addition to its geographic and periodical distribution. As a project for a doctoral thesis, the work can be considered less conclusive. Schiavi and Behr (2017) investigated the term "disruptive business model". The analysis is descriptive but comprehensive, beginning with an initial selection of 1,661 articles and examining the 19 most relevant papers published between 2004 and 2016 in detail. The authors verified the preponderance of applied studies in relation to theoretical approaches and suggest more bibliometric analyses as an extension of their study. $\mathrm{Li}$, Porter, and Suominen (2017) analyzed the dichotomy between the concepts of "disruptive technology" or "disruptive innovation" (DT or DI) and "emergent technology" (ET), identified a relationship between DI and ET, and advocated for a harmonized approach to embracing both concepts. Recently, Hopp, Antons, Kaminski, and Salge (2018b) mapped disruption-related papers and concentrated on the 84 most researched topics, analyzing the temporal dynamics of the field and suggesting the consolidation of peripheral or dissociated topics, together with the conciliation of terminologies.

Differently from the cited papers, this review focuses on the discussion between "disruptive innovations" as defined by Christensen and all other types of innovation that, even if not adherent to Christensen's concept, were named "disruptive innovation". We aim to analyze the literature that applies the term and identify differences and similarities between authors and related papers. A bibliometric approach is applied for the analysis of the delineated universe and helps to evaluate the prominence of Christensen in the selection, in addition to distinguishing and grouping authors associated with other connotations of the term.

\section{Evolution of the innovation debate}

The origin of studies on innovation with an explicit focus on organizations is not entirely clear, with specific contributions coming from different areas. From a wider perspective, if one looks at improvements in productivity achieved through the use of machines and new processes as innovations, the discussion has been going on since the time of Adam Smith. In his classic The Wealth of Nations ([1776] 2007), Smith characterized the division of labor as a facilitator of machine inventions, which expanded productivity and production and allowed greater economic development of contemporary societies. In recent times, Schumpeter (1912) emphasized the importance of entrepreneurial activities for technological development and consequent economic growth. The author's work is considered to be an important reference in many studies directed at organizations. Schumpeter's ([1942] 2014) vision of the innovative process evolved throughout his career, culminating in the recognition that resources, processes, and routines available to large corporations in concentrated markets provide advantages for these companies to innovate.
Over the years, more refined constructs have been developed for the benefit of both countries and organizations.

Among the first studies to mark the contemporary view of innovation from an organizational perspective are Utterback and Abernathy (1975) and Abernathy and Utterback (1978), which extended the analyses beyond cases of an incremental nature that occur with knowledge accumulation in established firms. The authors describe radical innovations as those associated with the recognition of new demand and the introduction of superior performance, without solely seeking to reduce costs with standard technologies. Such innovations would create recognized competitive advantages over the existing supply (Porter, 1985). In recent decades, innovations have come to be evaluated based on other dimensions, incorporating not only a technological aspect but also demand types (Abernathy \& Clark, 1985; Christensen, 1997) and a system facet (Henderson \& Clark, 1990). In the past, the one-dimensional view of innovation left gaps while explaining the progress of some technologies and organizations; therefore, it seems that more sophisticated models are required.

\section{Christensen's Disruptive Innovation}

The theory of disruptive innovation was developed in the 1990s by Clayton Christensen while pursuing his Doctorate in Business Management from the Harvard Business School and emerged as an attempt to shed light on why companies failed to identify that some innovations with less embedded technology threatened their dominant positions. This anomaly was articulated by Christensen and his colleagues (e.g., Bower \& Christensen, 1995; Christensen \& Bower, 1996; Christensen, 1997; Christensen \& Overdorf, 2000; Christensen \& Raynor, 2003; Christensen, Anthony, \& Roth, 2004) with important managerial lessons, including that paying exclusive attention to the best customers and the current values in an established company would increasingly disengage it from disruptive innovations and could jeopardize its future growth.

For Christensen, Anthony, and Roth (2004), disruptive innovations "either create new markets, bring new attractiveness to nonconsumers, or offer more convenience, at lower prices, to lower-income consumers in an existing market" (p.321). Additionally, domination by a new entrant in a breakthrough movement in an established market may occur, but it is not necessary to characterize an innovation as disruptive in Christensen's sense.

According to Christensen's theory, firms that innovate in a radical or incremental manner in a struggle to improve their overall quality in order to further improve their products, usually pursue the attributes of a dominant design. Such firms practice so-called "sustaining innovations" and compete to serve a class of unsatisfied consumers who would pay more for improvements in features or attributes of the product consumed. This group should comprise the majority of firms and innovations. On the other hand, there are companies that seek to serve satisfied consumers and accept or desire a lower quality or quantity of certain attributes. Such companies practice low-end disruptive strategies. As an example, Christensen (1997) presents 31/2- 
inch floppy disk readers as low-end innovators over their 51/4-inch competitors in the 1980s. Until that date, although the $3 \frac{1}{2}$ disks were smaller than the dominant $5 \frac{1}{4}$ disks, they did not meet the storage capacity required by leading minicomputer and PC makers and were thus produced by companies that served a limited and less profitable market comprised of the nascent laptop industry. Over time, through incremental innovations, the $3 \frac{112}{2}$ floppy disks met the standard storage capacity required by the minicomputer and PC market, capturing a significant portion of the market from its $5 \frac{1}{4}$ competitors. A similar pattern was found in the previous period:

For example, the 8-inch floppy disk would store $20 \mathrm{MB}$ when it was first introduced, while the primary floppy disk market at that time was mainframe and required $200 \mathrm{MB}$ disk. Not surprisingly, leading computer producers rejected the architecture of the 8-inch floppy disk initially. As a result, vendors, whose mainstream products consisted of 14-inch disks with more than $200 \mathrm{MB}$ of capacity, did not aggressively track disruptive products. (Bower \& Christensen, 1995, p.45)

Finally, Christensen's theory states that there are innovations that bring new consumers to the market, previously untapped due to lack of ability to consume or enjoy the good (or service) or insufficient resources. By making products and services simpler and cheaper, firms enable the emergence of consumers requesting attributes that are different from those demanded by the conventional market. Firms that practice such strategies are called new-market disruptive innovators. The Sony Walkman is a typical example (Christensen, 1997), as it personalized music to people who walked or jogged and had no option available except for portable radio alternatives. More recently, Kenya's Vodafone-Safaricom M-Pesa provided another example of a newmarket disruptive innovation when it started offering Short Message Service (SMS) payment services at a time when more sophisticated and faster technologies were available but did not reach a significant portion of potential consumers (Ngugi, Pelowski, \& Ogembo, 2010).

Figure 1. Model of the Disruptive Innovation Theory developed by Christensen, Anthony, and Roth (2004)

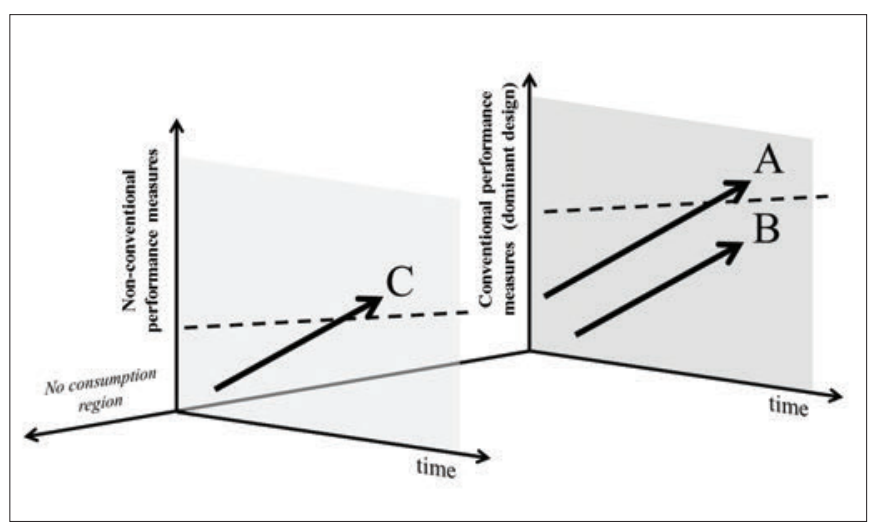

Figure 1 summarizes the essential elements of Christensen's theoretical model. The dotted lines are the evolutionary trajectories of the attributes demanded by the average consumer, and the thick arrows represent the technological evolution of different companies.
Company A is one that seeks to increase the supply of attributes valued by its current customers, and its innovations are called sustainable. Company B, on the other hand, innovates by reducing the number of attributes in its products (low-end disruptive innovation) and potentially, but not necessarily, achieves this goal in the future. Finally, company $\mathrm{C}$ captures nonconsumers, who place more value on a different set of attributes than the design favored by dominant consumers (new-market disruptive innovation).

Christensen argues that his approach is subject to fewer observable anomalies than previous theoretical constructs, especially with the incorporation of its most recent advances. In Christensen (2006), for example, the scope of the theory has been expanded and it now considers changes in business models as innovation, preferring the term "disruptive innovation" to the previous "disruptive technology". Since the second edition of his book, The Innovator's Dilemma, in the year 2000, Christensen has pointed out that resources, processes, and values would delineate an organization's innovative possibilities by building up relevant knowledge applicable to firms threatened by disruptors.

\section{Criticism of Christensen's approach}

Christensen's (1997) approach provided an important theoretical advance. It added constructs and filled gaps left by previous theories of innovation. Even critical authors recognize the virtues of the approach and suggest that we do not abandon it (e.g., King \& Baatartogtokh, 2015). However, similar to any theoretical construction, it does not evolve without criticism.

Henderson (2006), for example, exposes the fact that the theory is based on the cognitive failures of agents who do not identify disruptive opportunities within the spectrum of indicators already consolidated by the dominant design and their current clients. The author argues for the rationality of the leaders of organizations that do not respond to disruptive innovations, given the characteristics of competencies already present in established firms. The decision to serve current customers in the mainstream market, which provides the best profits, rather than pursuing a disruption with a lesser probability of success and lower profitability, would be reasonable and consistent with the empirical data. In reference to disruptive innovations that create or rely on new patterns of market preferences, the author states that it is "particularly difficult for established firms to respond effectively for reasons that are embedded in firm competencies" (2006, p.9).

For Markides (2006), the theory developed by Christensen has been mistakenly used in the analysis of different disruptive innovations. Although Christensen and Raynor (2003) expanded the scope of disruptive innovations beyond the technological context previously outlined in Christensen (1997) to also encompass business model and products, Markides (2006) emphasizes that disruptive innovations may have some effects on competition that must be administered in a manner different than that advocated by Christensen (1997). Markides' argument is that there are different kinds of disruptive innovations and that they should be treated differently. The author explores 
two phenomena present in the literature: innovation in business model and radical product innovation. According to Markides, these two types of innovations threaten unprepared firms in a manner similar to Christensen's (1997) description, but inhibiting excessive proximity to customers, as suggested by Bower and Christensen (1995), would not be the most appropriate approach to innovations that were not purely technological.

While some authors argue that upmarket innovations that improve the quality of a product or service may be disruptive innovations (Markides, 2006), Christensen, Raynor, and McDonald (2015) reject this idea and reiterate that disruptive innovations are exclusively low-end or new market innovations. Improving what is already being offered to the mainstream market is not a disruptive innovation in Christensen's sense, but rather is a sustaining innovation.

\section{Bibliometric analysis}

The evaluation begins with the selection of articles in the Web of Science database from 1995 to 2017 that have the terms "disrupt ${ }^{*}$ innovat ${ }^{*}$ " or "disrupt ${ }^{\star}$ technolog ${ }^{\star}$ " in their titles, abstracts or keywords. This method generated 876 papers and 2,299 authors, amounting to 11,941 citations, excluding self-citations. Because the set of articles was also filtered based on the category of interest, (e.g., Business \& Economics), the selection was restricted to 333 publications by 675 different authors. As an additional filter, only articles with at least one citation were kept, resulting in a sample of 266 articles in 82 journals by 500 different authors. We restrict the sample further by selecting the ten journals with the highest JCR indices, listed in Table 1, resulting in a universe of analysis consisting of 140 articles.
Table 1. Search filters - Web of Science database

\begin{tabular}{|c|c|c|c|}
\hline Codes & Filters & \# papers & \# authors \\
\hline (A) & $\begin{array}{l}\text { Title, abstract or key-word contai- } \\
\text { ning "disrupt* innovat*" or "disrupt* } \\
\text { technolog*" }\end{array}$ & 876 & 2.299 \\
\hline (B) & Category: Business \& Economics & 333 & 675 \\
\hline (C) & Number of citation $>0$ & 266 & 500 \\
\hline (D) & $\begin{array}{l}\text { Journals: (D1) Technological Fo- } \\
\text { recasting and Social Change; (D2) } \\
\text { Journal od Product Innovation Ma- } \\
\text { nagement; (D3) Harvard Business } \\
\text { Review; (D4) Technovation; (D5) } \\
\text { Research-Technology Management; } \\
\text { (D6) Research Policy; (D7) Techno- } \\
\text { logy Analysis \& Strategic Manage- } \\
\text { ment; (D8) Creativity and Innova- } \\
\text { tion Management; (D9) International } \\
\text { Journal of Technology Management; } \\
\text { (D10) IEE Transactions of Enginee- } \\
\text { ring Management. }\end{array}$ & 140 & 301 \\
\hline
\end{tabular}

The temporal evolution of the publications in the universe of analysis begins in 1995 with Bower and Christensen's (1995) seminal article, Disruptive Technologies - Catching the wave, in which the "disruptive innovation" concept was still referred to by the term "disruptive technology". Between 1995 and 1999, there were no articles in the sample. The peak of representation occurred in 2013 with the publication of 17 articles. Table 2 summarizes the distribution of the number of publications in each journal in the research universe.

Table 2. Distribution of the number of articles by periodical and year of publication. Codes (D1) and (D10) follow as in Table 1

\begin{tabular}{|c|c|c|c|c|c|c|c|c|c|c|c|c|c|c|c|c|c|c|c|c|}
\hline \multirow[b]{2}{*}{ Journal } & \multicolumn{20}{|c|}{ Publication year } \\
\hline & $\stackrel{2}{2}$ & ஓ ঠ & ঠ্ণ & ్ํㅇ & ֻ̊̊ి & ঠ্ণ & 용 & ๖̊ & $\stackrel{ }{8}$ & $\stackrel{\infty}{\stackrel{ᄋ}{ᄋ}}$ & ஓి & $\stackrel{\circ}{\stackrel{0}{0}}$ & $\bar{\Xi}$ & 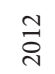 & $\stackrel{n}{\stackrel{n}{\sigma}}$ & 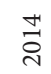 & 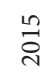 & $\underset{\sigma}{\stackrel{0}{0}}$ & $\stackrel{\curvearrowright}{\widetilde{N}}$ & 종 \\
\hline (D1) & & & & & & 4 & 2 & & 7 & 3 & 2 & 3 & & & 5 & 2 & 4 & 5 & 1 & 38 \\
\hline (D2) & & & & & & 1 & & & 1 & 2 & & 2 & 3 & 1 & 2 & 2 & 1 & & 1 & 16 \\
\hline (D3) & 1 & 1 & 1 & 3 & & 1 & & 1 & 1 & 1 & & & 1 & & 1 & & 1 & & & 13 \\
\hline (D4) & & & & 2 & & & & & & 1 & 1 & 3 & 2 & & & 2 & 2 & & & 13 \\
\hline (D5) & & & 1 & & & 1 & & & 2 & & 1 & 1 & 4 & 1 & & & 1 & & & 12 \\
\hline (D6) & & & & & & & & & 1 & 1 & & & & 2 & 2 & 1 & 1 & 3 & & 11 \\
\hline (D7) & & & & & & & 1 & & & & 2 & & & 3 & 3 & 2 & & & & 11 \\
\hline (D8) & & & & & & & & & & & & & 1 & 2 & 3 & 2 & & 1 & & 9 \\
\hline (D9) & & & & & 1 & 2 & & 1 & & 2 & & 1 & 1 & 1 & & & & & & 9 \\
\hline (D10) & & & & 2 & & & & & & 1 & & 1 & & 1 & 1 & 1 & & 1 & & 8 \\
\hline Total & 1 & 1 & 2 & 7 & 1 & 9 & 3 & 2 & 12 & 11 & 6 & 11 & 12 & 11 & 17 & 12 & 10 & 10 & 2 & 140 \\
\hline
\end{tabular}

Within this research universe, the core subjects selected were the 25 most cited articles, produced by 55 different authors, and representing more than $75 \%$ of the citations in the universe; that is, 3,215 citations out of a total of 4,281 from 140 articles. Then, after this selection of authors and their co-citations, the metadata were submitted to analysis, carried out with the support of the Bibexcel and Stata software. The set of the 25 articles selected is presented in the appendix. 
Assuming that authors can be identified with a single theoretical framework, the analysis of co-citations was made using the authors of the 25 papers selected as units of analysis, resulting in a total of 55 names. Based on these names and those present in the co-citation list, a network was constructed and the centrality and intermediation grades were calculated. The network is visualized in Figure 2, which was restricted to authors cited at least 300 times in the research universe and has distinct coloration for each of the two groups formed: Group 1 in red and Group 2 in green.

Figure 2. Author co-citation network

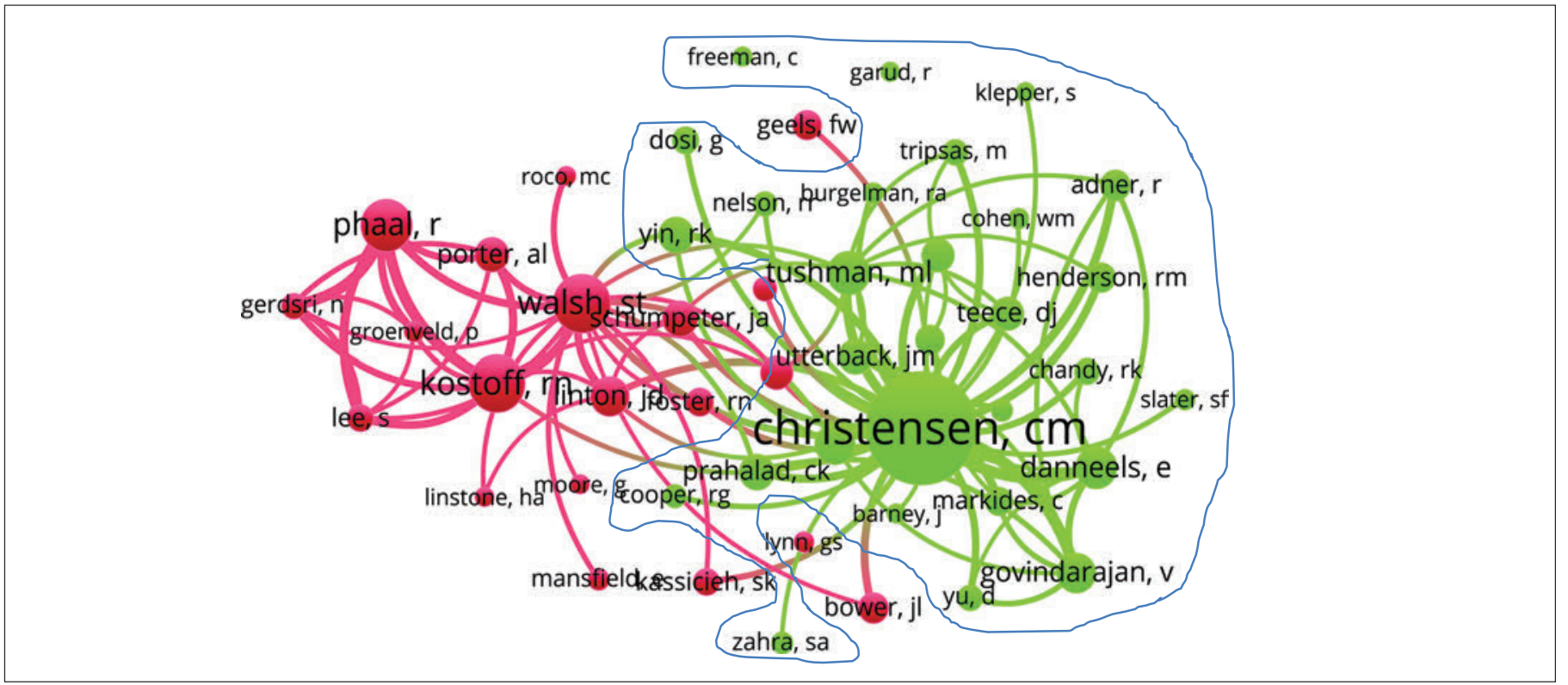

The clusters suggest that authors who are critical of some Christensen's ideas, such as Erwin Danneels, or even authors who employ a concept distinct from that proposed by Christensen, such as Michael Tushman, are in the same cluster (Group 2 (green)). On the other hand, Group 1 (red) contemplates authors whose papers focus more on the application of innovation management tools and techniques, such as technological roadmaps, and who rarely discuss the theoretical aspects common to other areas of investigation. The centrality and intermediation degrees for the authors calculated in the standard and normalized versions are presented in Table 3 and show that Christensen has both high centrality and intermediation, suggesting that the author not only concentrates attention but also aids in the development of the network close to several pairs, even from a different group.

Table 3. Grouping, degrees of centrality and intermediation of main authors

\begin{tabular}{|c|c|c|c|c|c|c|c|}
\hline \multirow{2}{*}{ Author } & \multirow{2}{*}{ Group } & \multicolumn{2}{|l|}{ Centrality } & \multirow{2}{*}{ Author } & \multirow{2}{*}{ Group } & \multicolumn{2}{|c|}{ Intermediation } \\
\hline & & Standard & Normalized & & & Standard & Normalized \\
\hline Bower J & 2 & 36 & 0.783 & Daim T & 1 & 321.00 & 0.155 \\
\hline Danneels E & 2 & 29 & 0.630 & Lee J & 1 & 315.51 & 0.152 \\
\hline Baker W & 2 & 25 & 0.543 & Christensen C & 2 & 259.45 & 0.125 \\
\hline Lee C & 1 & 21 & 0.457 & Newbert S & 1 & 178.10 & 0.086 \\
\hline Lee J & 1 & 21 & 0.457 & Phaal R & 1 & 165.11 & 0.080 \\
\hline Johnson M & 2 & 21 & 0.457 & Robinson D & 1 & 164.76 & 0.080 \\
\hline Gassmann O & 2 & 19 & 0.413 & Prusak L & 2 & 151.36 & 0.073 \\
\hline Lee $S$ & 1 & 19 & 0.413 & Baker W & 2 & 147.35 & 0.071 \\
\hline
\end{tabular}

Moreover, as this study took the approach of constructing groups by author, it was not possible to glimpse the situation in which the same author has works with distinct characteristics; for example, belonging to different groups. This is the case of Steve Walsh, who possesses the highest degree of intermediation. As an illustration of his importance, if one ignores the minimum node rule in each cluster, the author emerges at the head of a third cluster. To cover more details about the groups, the analysis continued with a focus on the keywords given by 
the original set of 140 articles and the construction of their network. The resulting map is shown in Figure 3, with a cluster-oriented cons- truction and a minimum of 13 occurrences, chosen ad hoc to improve visual representation of the network.

Figure 3. Keyword occurrence network

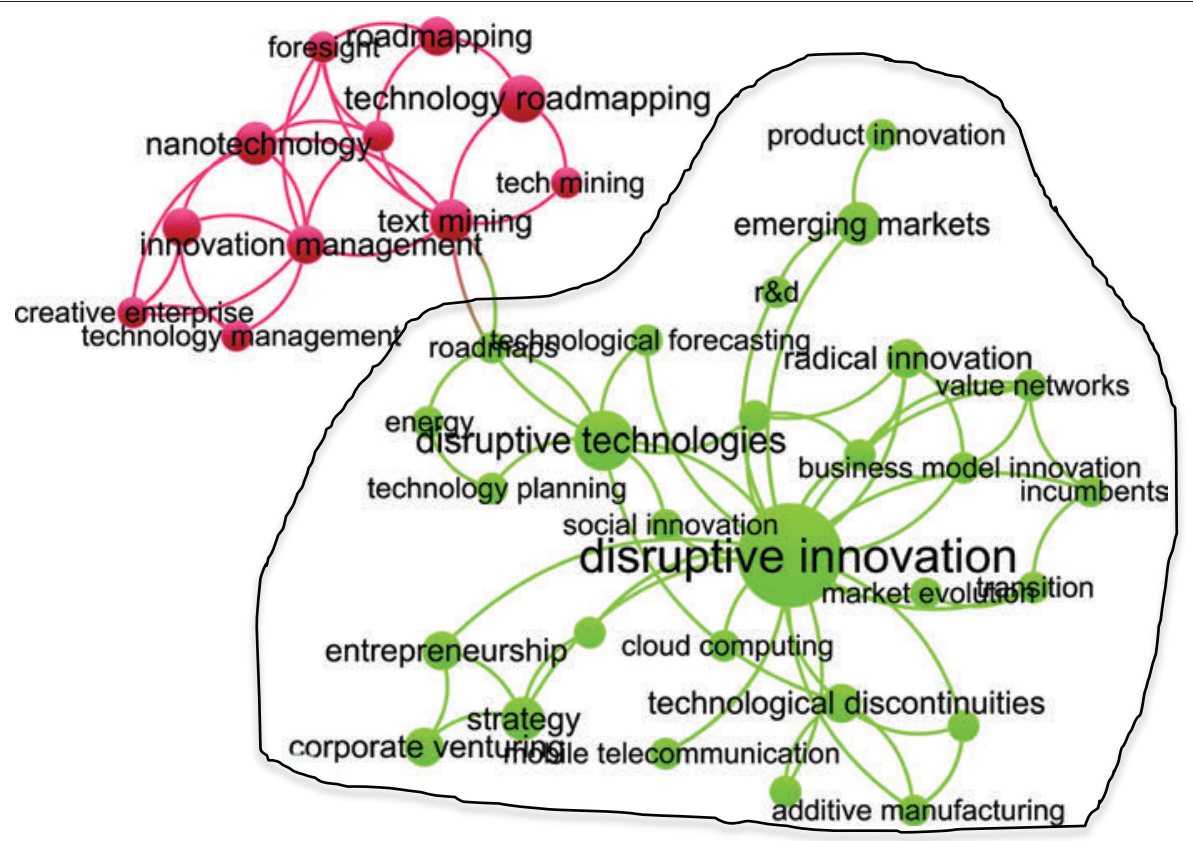

Figure 3 is in line with initial impressions that there is one group (red) which is associated with the development of management tools, such as the technology roadmap and is less concerned with discussing the term "disruptive innovation" or its meaning as suggested by Christensen. Disruptive innovations for this group are those that oppose incremental or architectural innovations and are usually taken as synonyms for radical or breakthrough innovations. This group has been more frequently featured in the journal Technological Forecasting and Social Change. On the other hand, the other group (green) exposes different typologies of innovation that are more associated with works that seek theoretical development in management disciplines, but which are criticized for having a retrospective view. They consist of texts written by Christensen and colleagues but also by authors who discuss or criticize their concepts (e.g., Daneels, 2004; Schmidt \& Druehl, 2008). They are part of the business and management community, with major contributions made by the Harvard Business Review and the Journal of Product Innovation Management.

As a final point, based on the exercise carried out, a composition was constructed with two major thematic groups related to disruptive innovations. This conciliation is presented in Table 4.

Table 4. Group composition of selected articles

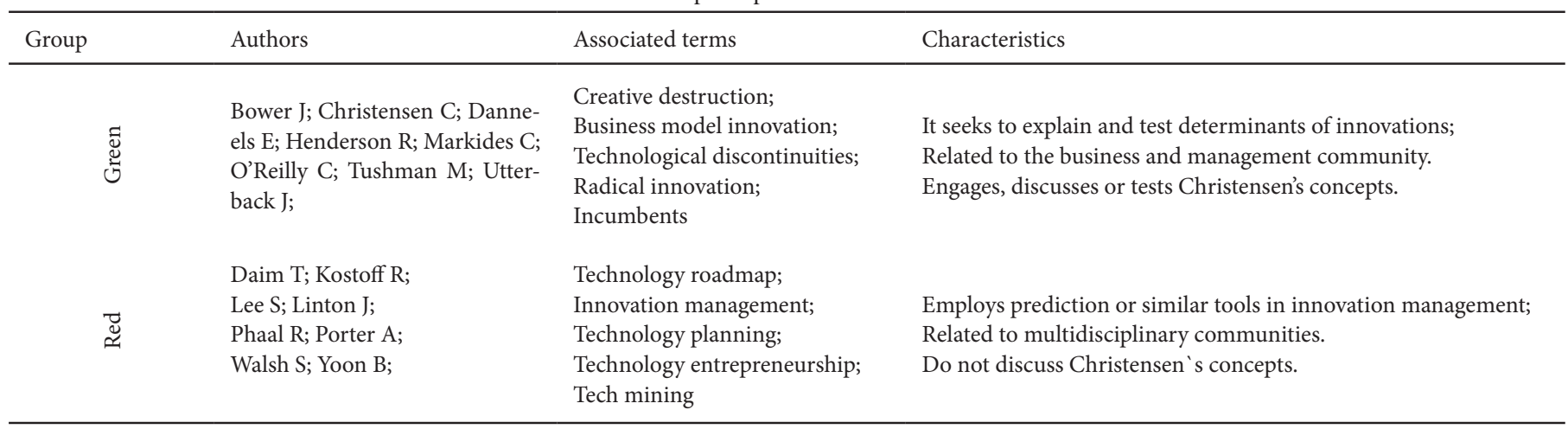

The Red subgroup is dedicated to assisting with the monitoring, planning, acquisition or employment of technologies, with a multidisciplinary focus and strong influence on engineering. Although the use of the term "disruptive innovation" is associated 
with radical events, the discussion about the conceptualization given by Christensen is almost nonexistent. The Green subgroup has a greater adherence to the area of business and strategy and presents more enthusiasm for theoretical constructions. It is common for this group to test or discuss the conception of disruptive innovation proposed by Christensen. The authors from this group do not always agree with Christensen's conceptualization, but it is in this group that eventual discussions about the term tend to occur.

\section{Final remarks}

The understanding of different types of innovation is relevant to the advancement of theoretical constructs and applications within organizations, an idea that has been accepted at least since Utterback and Abernathy (1975), and disruptive innovations should not be an exception. The present paper tried to map the main authors related to the theme and their respective publications. For readers less familiar with the debate, this enables the selection of important papers to obtain a better understanding of the insertion of Christensen into the research universe. For more experienced practitioners and academics, the work provides a panoramic view of the field associated with disruptive innovation, with an explicit suggestion for further development of the theory in the last paragraph.

Overall, the analysis showed that Christensen's prominence in the debate is evident. Even if a reader considers Christensen's disruptive innovation definition trivial, incomplete, or misleading, his name has acquired distinction in the literature. In addition to his high degree of centrality, he also has one of the highest degrees of intermediation. Although simpler terminology and definitions may be preferred (Hopp et al., 2018b), a semantic narrowing of the term "disruptive innovation" seems to be necessary for the consequent development of innovation theories. The narrowing of the concept has two advantages. Firstly, it provides a clearer path to theoretical improvements. More precise constructs may reduce undesirable ambiguities and help us to better understand how firms cope with disruptive innovations and introduce them. Secondly, it helps feed our hunger for knowledge on disruptive innovation and facilitates the collection of data and the production of missed quantitative-related studies. Along this line, instead of looking for a term best suited to explaining the multifaceted phenomenon of disruptive innovations, it may be the case that we are facing different phenomena and, if this is so, a different term is desirable. Consequently, for those contemplating Christensen's concept of disruptive innovation, the use of alternative terminology such as the "Christensen effect" (Christensen, 2006, p. 42) seems to be an attractive suggestion for further development of the theory.

\section{References}

Abernathy, W. J., \& K. B. Clark. (1985). Innovation: mapping the winds of creative destruction. Research Policy, 14(1), 3-22. https:// doi.org/10.1016/0048-7333(85)90021-6

Abernathy, W. J., \& Utterback, J. M. (1978). Patterns of industrial innovation. MIT Technology Review, 80(7), 41-47.
Besanko, D., Dranove, D., \& Shanley, M. (2004). Economics of strategy. Hoboken, NJ: Wiley.

Bower, J. L., \& Christensen, C. M. (1995). Disruptive technologies: Catching the wave. Harvard Business Review, 73(1), 43-53.

Cândido, A. C. (2011). Inovação disruptiva: Reflexões sobre as suas características e implicações no mercado. Working paper 05-2011. Research Centre on Enterprise and Work Innovation. Faculdade de Ciências e Tecnologia da Universidade de Lisboa. Portugal. Retrieved from https://run.unl.pt/bitstream/10362/6912/1/WPSeries_05_2011 ACC\%C3\%A2ndido-1.pdf

Christensen, C. M. (1997). The Innovator's dilemma: When new technologies cause great firms to fail. Boston: Harvard Business School Press.

Christensen, C. M. (2006). The ongoing process of building a theory of disruption. Journal of Product Innovation Management, 23(1), 3955. https://doi.org/10.1111/j.1540-5885.2005.00180.x

Christensen, C. M., \& Bower J. L. (1996). Customer power, strategic investment, and the failure of leading firms. Strategic Management Journal, 17(3), 197-218. https://doi.org/10.1002/(SICI)10970266(199603)17:3<197::AID-SMJ804>3.0.CO;2-U

Christensen, C. M., \& Overdorf, M. (2000). Meeting the challenge of disruptive change. Harvard Business Review, 78(2), 65-76.

Christensen, C. M., \& Raynor, M. (2003). The Innovator's solution: creating and sustaining successful growth. Boston: Harvard Business School Press.

Christensen, C. M., Anthony, S. D., \& Roth, E. A. (2004). Seeing what's next. Boston: Harvard Business School Press.

Christensen, C. M., Raynor, M., \& McDonald, R. (2015). What is disruptive innovation? Harvard Business Review, 93(12), 44-53.

Daneels, E. (2004). Disruptive technology reconsidered: A critique and research agenda. Journal of Product Innovation Management, 21(4), 246-258. https://doi.org/10.1111/j.07376782.2004.00076.x

Garud, R., Kumaraswamy, A., \& Langlois, R. (2003). Managing in the modular age: Architectures, networks, and organizations. Oxford: Blackwell.

Henderson, R. (2006). The innovator's dilemma as a problem of organizational competence. Journal of Product Innovation Management, 23(1), 5-11. https://doi.org/10.1111/j.1540-5885.2005.00175.x

Henderson, R. M., \& Clark, K. B. (1990). Architectural innovation: The reconfiguration of existing product technologies and the failure of established firms. Administrative Science Quarterly, 35(special issue: Technology, Organizations, and Innovations), 9-30. 
Hill, C. W. L., Jones, G. R., \& Schilling, M. A. (2015). Strategic management theory \& cases: An integrated approach. Stanford: Cengage.

Hopp, C., Antons, D., Kaminski, J., \& Salge, T. O. (2018a). Disruptive innovation: Conceptual foundations, empirical evidence, and research opportunities in the digital age. Journal of Product Innovation Management, 35(3), 446-457. https://doi.org/10.1111/jpim.12448

Hopp, C., Antons, D., Kaminski, J., \& Salge, T. O. (2018b). The topic landscape of disruption research: A call for consolidation, reconciliation, and generalization. Journal of Product Innovation Management, 35(3), 458-487. https://doi.org/10.1111/jpim.12440

King, A. A., \& Baatartogtokh, B. (2015). How useful is the theory of disruptive innovation? MIT Sloan Management Review, 57(1), 70-90.

Li, M., Porter, A. L., \& Suominen, A. (2018). Insights into relationships between disruptive technology/innovation and emerging technology: A bibliometric perspective. Technological Forecasting and Social Change, 129(4), 285-296. https://doi.org/10.1016/j.techfore.2017.09.032

Markides, C. (2006). Disruptive innovation: In need of better theory. Journal of Product Innovation Management, 23(1), 19-25. https://doi. org/10.1111/j.1540-5885.2005.00177.x

Markides, C. (2013). Disruptive reality: making the leap into developed markets. Business Strategy Review, 24(3), 36-43. https://doi. org/10.1111/j.1467-8616.2013.00970.x

Nugi, B., Pelowski, M., \& Ogembo, J. G. (2010). M-Pesa: A case study of the critical early adopters' role in the rapid adoption of mobile banking in Kenya. The Electronic Journal on Information Systems in Developing Countries, 43(1), 1-16. https://doi.org/10.1002/j.1681-4835.2010.tb00307.x

Organisation for Economic Cooperation and Development (OCDE). (2005). Oslo Manual: The measurement of scientific and technological activities, 3rd Edition. OECD, Statistical Office of the European Communities. OECD Publishing, Paris.

Pilkington, A. (2009). Exploring the disruptive nature of disruptive technology. Paper presented at the 2009 International Conference on Industrial Engineering and Engineering Management (IEEM), Hong Kong.
Porter, M. E. (1985). Competitive advantage: Creating and sustaining superior performance. New York: Free Press.

Schiavi, G. S., \& Behr, A. (2017). Modelos de negócios disruptivos: um estudo bibliométrico da produção científica disponível em bases de dados nacionais e internacionais. Paper presented at the 2017 International Conference on Information Resources Management (CONFIRM), Santiago de Chile. Retrieved from https://aisel.aisnet.org/ confirm2017/19

Schmidt, G. M., \& Druehl, C. T. (2008). When is a disruptive innovation disruptive? Journal of Product Innovation Management, 25(4), 347-369. https://doi.org/10.1111/j.15405885.2008.00306.x

Schumpeter, J. A. (1912). The theory of economic development. Cambridge (MA): Harvard University Press.

Schumpeter, J. A. (2014). Capitalism, socialism and democracy. Floyd, VI: Impact Books. Original published in 1942.

Smith, A. (2007). An inquiry into the nature and causes of the wealth of nations. Edited by Sálvio M. Soares. MetaLibri, v.1.0p. Retrieved from http://metalibri.wikidot.com/title:an-inquiry-into-the-nature-andcauses-of-the-wealthof.Original work published in 1776.

Souza, I. D. S., \& V. P. Takahashi. (2012). A vision of the future through prospective scenarios: A tool for the anticipation of disruptive innovation. Future Studies Research Journal, 4(2), 102-131.

The Economist. (2011). Aiming high: we launch a quarterly review of business books by considering six of the best. Business books. Retrieved from http://www.economist.com/node/18894875

Trott, P. (2008). Innovation management and new product development. New York: Prentice Hall.

Utterback, J. M., \& W. J. A. Abernathy. (1975). Dynamic model of process and product innovation. Omega - International Journal of Management Science, 3(6), 639-656. https://doi.org/10.1016/03050483(75)90068-7 


\section{Appendix}

Table A. Summary of selected articles

\begin{tabular}{|c|c|c|c|c|}
\hline Reference & Title & Journal & \# Authors & Citations \\
\hline O’Reilly and Tushman (2004) & The Ambidextrous Organization & Harvard Business Review & 2 & 602 \\
\hline Bower and Christensen (1995) & Disruptive Technologies - Catching The Wave & Harvard Business Review & 2 & 527 \\
\hline Johnson et al. (2008) & Reinventing Your Business Model & Harvard Business Review & 3 & 328 \\
\hline Danneels (2004) & Disruptive Technology Reconsidered: A Critique ... & Journal Of Product Innov Manag & 1 & 256 \\
\hline Walsh (2004) & Roadmapping A Disruptive Technology ... & Tech Forec \& Social Change & 1 & 144 \\
\hline Christensen et al. (2006) & Disruptive Innovation For Social Change & Harvard Business Review & 4 & 142 \\
\hline Kostoff et al. (2004) & Disruptive Technology Roadmaps & Tech Forec \& Social Change & 3 & 134 \\
\hline Song et al. (2008) & Success Factors In New Ventures: A Meta-Analysis & Journal Of Product Innov Manag & 4 & 125 \\
\hline Baker and Sinkula (2007) & $\begin{array}{l}\text { Does Market Orientation Facilitate Balanced Innova- } \\
\text { tion ... }\end{array}$ & Journal Of Product Innov Manag & 2 & 122 \\
\hline Lee and Park (2005) & Customization Of Technology Roadmaps ... & Tech Forec \& Social Change & 2 & 90 \\
\hline Lee et al. (2009) & $\begin{array}{l}\text { Business Planning Based On Technological Capabili- } \\
\text { ties... }\end{array}$ & Tech Forec \& Social Change & 4 & 89 \\
\hline Prusak and Cohen (2001) & How To Invest In Social Capital & Harvard Business Review & 2 & 88 \\
\hline Lee et al. (2013) & An Integrated Service-Device-Technology Roadmap ... & Tech Forec \& Social Change & 3 & 66 \\
\hline Daim and Oliver (2008) & Implementing Technology Roadmap Process ... & Tech Forec \& Social Change & 2 & 66 \\
\hline Zeschky et al. (2011) & Frugal Innovation In Emerging Markets... & Research-Technology Manag. & 3 & 63 \\
\hline Robinson and Propp (2008) & Multi-Path Mapping For Alignment Strategies... & Tech Forec \& Social Change & 2 & 63 \\
\hline Schmidt and Druehl (2008) & When Is A Disruptive Innovation Disruptive? & Journal Of Product Innov Manag & 2 & 61 \\
\hline
\end{tabular}


